\title{
Intrauterine Sexual Differentiation: Biosyntesis and action of Sexual Steroid Hormones
}

\author{
Amilton Cesar dos Santos ${ }^{1 *}$, Diego Carvalho Viana ${ }^{1}$, Gleidson Benevides de Oliveira ${ }^{2}$, Luis \\ Miguel Lobo ${ }^{1}$ and Antônio Chaves Assis-Neto ${ }^{1}$ \\ ${ }^{1}$ Setor de Anatomia dos Animais Domésticos e Silvestres; Departamento de Cirurgia; Faculdade de Medicina \\ Veterinária e Zootecnia; Universidade de São Paulo; São Paulo - SP - Brasil. ${ }^{2}$ Departamento de Ciência Animal; \\ Universidade Federal Rural do Semiárido; Mossoró - RN - Brasil
}

\begin{abstract}
The objective of this review was to describe sexual differentiation events in mammals, relating them to biosynthesis of sexual steroid hormones and their mechanisms of action. Cholesterol is the precursor of sexual steroid hormone biosynthesis via action of several enzymes converting these hormones. Progestagens hormones serve as substrate for the production of androgens, which in turn serve as substrate for estrogen hormones. These hormones are responsible for sexual differentiation and reproductive cycles of mammals. Sexual differentiation process comprises determining the sexual chromosomes $X X$ or $X Y+S R Y$ and other genes linked to them, differentiation of gonads in testis or ovary, differentiation of internal and external male or female genital organs from undifferentiated anatomical structures present in the embryo, which is dependent on the presence or absence of testes and the production of anti-Müllerian hormone and testosterone; and secondary sexual differentiation, which is the response of various tissues to hormones produced by the gonads, interacting with genes linked to sexual chromosomes to increase or decrease the differences in sexual phenotype. However, some differences between the sexes and some anomalies of sexual differentiation are not explained only by these sexual hormonal effects, but also by the effect of genes encoded in sexual chromosomes.
\end{abstract}

Key words: P450 cytochrome,Sexual differentiation, Müllerian ducts, Wolff duct,Steroidogenesis

\section{INTRODUCTION}

Sexuality and its expression contribute to some of the most important aspects of human behavior and is a powerful, complex bio-psycho-social process (Bernardo-Filho et al. 2008). Basic studies related to embryology and sexual differentiation of the genital tract are essential to understand several diseases that affect mammals, mainly anomalies and malformations related to intersexuality (Domenice et al. 2002; Gaucher et al. 2004; Blaschko et al. 2012; Tannour-Louet et al. 2014).Complete descriptions of genomes of many species are emerging, which describe each gene encoding different proteins (Gaucher et al. 2004). In addition, studies related to inter-protein interaction, steroidogenic enzymes in the synthesis of hormones and their receptors (Bondesson et al. 2014) and their impact on physiology (Nakamura 2010) are currently being conducted.

Two related models for sexual differentiation have been proposed: the first, which was predominant during the twentieth century, was first described by Phoenix et al. (1959) and detailed by Jost (1965). This model is described in several classic textbooks of developmental biology (Wolpert 1998; Moore and Persaud 2008; Sadler 2012), physiology (Costanzo 1998) and genetics (Nora

*Author for correspondence: amiltonsantoss@bol.com.br 
and Fraser 1989). This model describes that the determining factors for the processes of sexual determination and differentiation in humans and most mammals are closely associated with the presence or absence of the $\mathrm{Y}$ chromosome: males have $\mathrm{XY}$ chromosomes and females have $\mathrm{XX}$ chromosomes. In this sense, the pivotal event of sexual determination is the specialization of gonads in testicles $(\mathrm{XY}+\mathrm{SRY})$ or ovaries $(\mathrm{XX})$, while the other differences between the sexes are secondary effects produced by sexual steroid hormones produced in these gonads, particularly androgens by testicles (Phoenix et al. 1959; Jost 1965; Nef and Parada 2000; Nakamura 2010).

The second model, recently proposed by Arnold (2009) describes that the sexual chromosomes acts differently at the cellular level, depending on the $\mathrm{XX}$ or XY factors. In this sense, the presence or absence of SRY (sex determining region on the Y chromosome) would be directly related to gonadal differentiation and different proportions of hormones produced by the gonads (ovaries and testes), associated with the differences in organization and activation of these hormones at tissue level. Another relevant factor is the sexual tendency favored by genes $\mathrm{X}$ and $\mathrm{Y}$. To summarize all these factors, the author suggests that hormones and direct genetic factors interact to increase or decrease male and female sexual differences.

Several studies have shown that some sexual differences are not explained by these sexual hormone effects, but induced by the effect of encoded-genes on the sexual chromosomes (Arnold 2009). Thus, great importance must be given to sexual differentiation processes during embryonic and fetal period and its relationship to various diseases, which are generally related to genic mutations (Blaschko et al. 2012; Bondesson et al. 2014; Tannour-Louet et al. 2014), especially those related to the biosynthesis of sexual steroid hormones associated with steroidogenic enzymes (Gaucher et al. 2004; Miller 2012) or antiMüllerian hormone (Nef and Parada 2000; Okay 2003). In addition to the pathologies of sexual differentiation, importance has also been given to interspecific dimorphism during ontogeny in experimental models used for studies on sexual differentiation (Conley et al. 2006; Yang et al. 2010; Blaschko et al. 2012; Santos et al. 2014a, 2015).

The aim of this study was to collect data about the genetic, anatomic and physiologic features of sexual differentiation mediated by sexual steroid hormones and to relate the mechanism of action of these hormones to several cases of diseases related to intersexuality and other diseases of male and female genital organs. Thus, the biosynthesis of sexual steroid hormones and their role in sexual differentiation of the male and female genital tract, the ontogeny of male and female genital tract, and pathologies related to the mutation in the genes evolved in the production of hormones and their receptors related to sexual differentiation are described in this study.

\section{SEXUAL STEROID HORMONES}

Hormones are regulatory substances that alter the rates in which reactions occur without contributing to the mass or energy for this reaction. These substances contribute to homeostasis, since them influence the metabolic reactions and cellular differentiation, and the processes of development, maturation and aging (Norman and Litwack 1997; Praporski et al. 2009).

Sexual steroid hormones are those involved in the reproductive process and sexual differentiation in mammals. They can be produced in the male and female gonads, adrenal glands and the placenta during pregnancy (Costanzo 1998; Pelley 2007) and occasionally in other non-specific tissues (Conley and Hinshelwood 2001). These hormones are responsible for the positive or negative feedback mechanism between gonads and hypothalamic-pituitary axis (Norman and Litwack 1997; Costanzo 1998).

The enzymes are responsible for biotransformation reactions and are present in the entire organism (Pelley 2007). The components of P450 system are considered hemeproteins, and in mammals, these enzymes are encoded by 10 gene families started by CYP, cytochrome P450. Over 100 genes coding cytochrome P450 enzymes with different specificities in humans are found (Stryer 1996). The hydroxylation reaction carried out by the enzymes of the cytochrome P450 family play an important role in cholesterol synthesis from squalene and conversion of cholesterol to steroid hormones (Miller 2012). In these hydroxylations, NADPH and $\mathrm{O}_{2}$ are required (Pelley 2007; Praporski et al. 2009; Viana et al. 2015). Furthermore, several other enzymes also participate in the production of different classes of 
sexual steroid hormones as outlined below (Fig. $1)$.

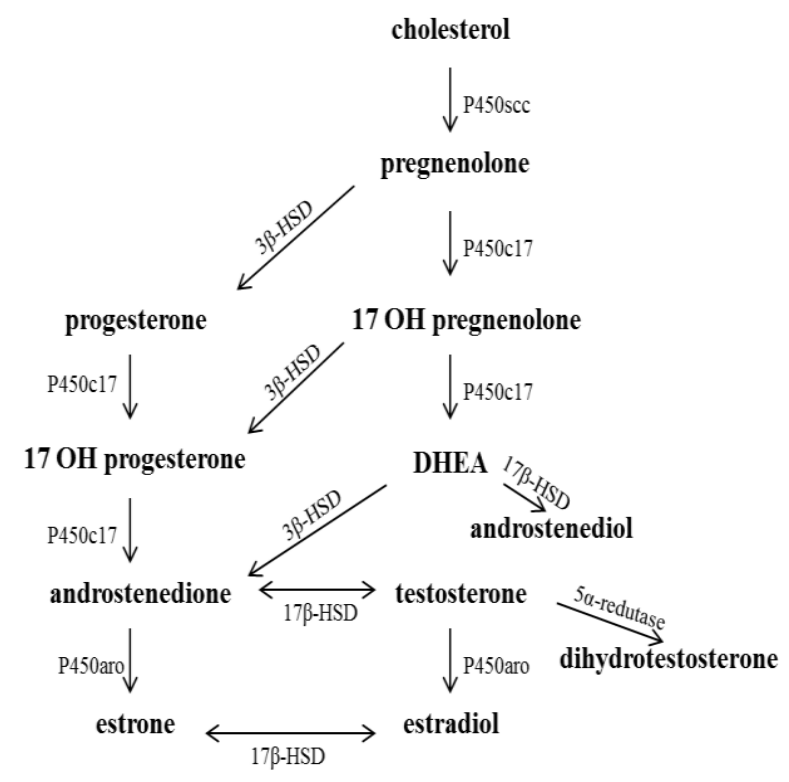

Figure 1 - Synthetic route of the main sexual steroid hormones. Note that each hormone is derived from a hormone of another class and that the steroidogenic enzymes are responsible for the conversion of these hormones. In addition, some enzymes are able to perform two-way conversion. Legend: Steroid cleavage chain (scc); hydroxysteroid dehydrogenase (HSD); dehydroepiandrosterone (DHEA); hydroxylase $(\mathrm{OH})$; aromatase (aro).

Cholesterol, first described in Konrad Block in the 1940s (Stryer 1996) is the precursor of five main classes of steroid hormones; progestagens, which give rise to glucocorticoids, mineralocorticoids (Pelley 2007; Miller 2012) and androgens, beyond estrogens derived from androgens (Praporski et al. 2009; Bondesson et al. 2014).

Among the sexual steroid hormones, progestagens have 21 carbon atoms in their structure. The progestagens hormones, such as progesterone are produced from pregnenolone (Domenice et al. 2002) in the corpus luteum of the ovary, placenta, and adrenal cortex (Costanzo 1998; Domenice et al. 2002) and are responsible for preparing the lining of uterus for implantation of fertilized oocyte (Pelley 2007). Progesterone plays an important role in the maintenance of pregnancy in mammals (Stryer 1996; Norman and Litwack 1997; Pelley 2007).
Androgens contain 19 carbon atoms (Norman and Litwack 1997) and are mainly produced in the testes, ovaries, placenta and adrenal gland (Miller 2012) from progestagens hormones (Conley and Hinshelwood 2001; Gaucher et al. 2004). Androgens are responsible for the sexual differentiation of external genitalia and development of secondary sexual characteristics in males (Yamada et al. 2003; Blaschko et al. 2012; Tannour-Louet et al. 2014) and act as substrate for estrogen hormones production (Conley and Hinshelwood 2001; Bondesson et al. 2014).

The estrogen hormones have 18 carbon atoms and are produced from androgen in cells of granular layer of the ovarian follicle, in placenta, testes and adrenal glands but can also be produced in other organs (Simpson et al. 2002). These hormones are necessary for the development of female secondary sexual characteristics (Nef and Parada 2000; Yang et al. 2010).

Estrogens together with progesterone participate in the ovarian cycle (Norman and Litwack 1997). The estrone and 17- $\beta$-estradiol are primary estrogens hormones. The first is derived from androstenedione and the second is derived from testosterone by aromatase action (Simpson et al. 2002; Gaucher et al. 2004; Bondesson et al. 2014). The lower expression of cytochrome P450 aromatase in the placenta may promote fetal exposure to higher levels of androgens, which influences the development and masculinization of female. However, the main function of placental aromatization of androgens that occurs during genital differentiation has not been studied in many species (Conley et al. 2006).

\section{EMBRYOLOGY OF SEXUAL DIFFERENTIATION IN MAMMALS}

The process of sexual differentiation in mammals follows this pattern: the determination of chromosomal sex, which is established at fertilization (Nakamura 2010), where male contain $\mathrm{XY}$ chromosomes and female XX chromosomes; differentiation of undifferentiated gonads in testicle or ovary (Arnold 2009); differentiation of both internal and external male or female genital organs from undifferentiated structures present in the embryo (Jost 1965; Nef and Parada 2000; Mello et al. 2005; Blaschko et al. 2012).

Mammalian species begin embryonic development without phenotypic sexual 
differentiation, and an ovarian is not required for the female phenotype, but a testicle is essential for the development of a male phenotype (Jost 1965; Blaschko et al. 2012). Arnold (2009) suggested that the absence or presence of the SRY gene would determine the gonadal differentiation, and then influence differently an XX or XY individual from hormones produced by the differentiated testicle or ovary.

In this regard, the SF-1, Lhx-1 and WT-1 genes (Nef and Parada 2000) appear to be essential for the preparation of bypotential gonadal tissue, in addition to DAX-1, DMRT and ATRX genes located on the sexual chromosomes and, WNT-4, located in the autosomes (Domenice et al. 2002). Beyond that genes involved in gonadal differentiation genes as SOX9 facilitates Sertoli cell differentiation, GATA-4 and FOG-2 perform male gonandogenesis, WNT-4 the Mullerian duct formation, DAX-1 female gonandogenesis, SHH (sonic hedgehog) plays genital tubercle development, WNT-5 and FGF-8 acts downstream of SHH in genital tubercle development, and ATF3 (Blaschko et al. 2012) and VAMP-7 (TannourLouet et al. 2014) is up-regulated in hypospadias.

Studies in mutant mice with four different conformations: $\mathrm{XX}$ with testicle or ovary and $\mathrm{XY}$ with testicles or ovaries showed that the presence of chromosomes $\mathrm{XX}$ or $\mathrm{XY}$ was directly related to SRY factor and testosterone for the formation of different phenotypes (Arnold and Chen 2009). The different genetic conformations showed no phenotypic differences when they had the same type of gonad, excluding chromosomal difference and showing participation of the different hormones produced in the ovaries or testicles interacting with genes linked to the sexual chromosomes, and others located in the autosomes (Arnold 2009).

Studies have shown the involvement of estrogens and their receptors in the sexual differentiation of the external genitalia in mice (Yang et al. 2010; Bondesson et al. 2014) and the influence of VAMP-7 gene in the modulation of estrogen receptors during differentiation of the external genitalia in humans(Tannour-Louet et al. 2014).

Details of the models for sexual differentiation based on the widely disseminated model in the twentieth century (Phoenix et al. 1959) and the unified model, which lists the possible factors that determine the sexual differentiation in mammals (Arnold 2009) (Fig. 2) are given below.
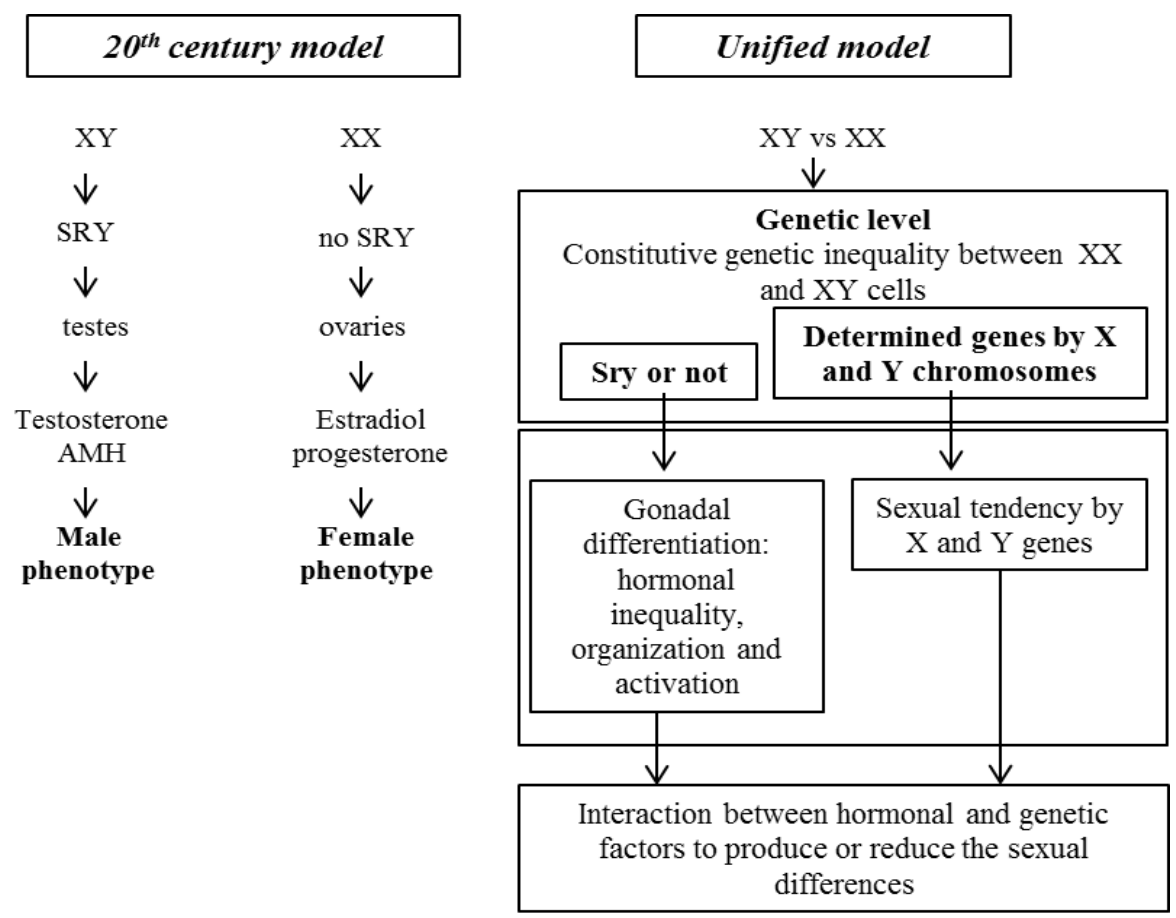

Figure 2 - Illustration demonstrating the models used to explain the process of sexual differentiation in mammals. 
In the model predominantly employed in the twentieth century (Phoenix et al. 1959; Jost 1965), sexual differentiation of the gonads is associated with male-specific effects of the SRY gene. Once the gonads differentiate in the testicles or ovaries, they secrete different sexual steroid hormones. Thus, based on the organizational-activation theory, testicular hormones testosterone and antiMüllerian act in various tissues in the fetal and neonatal periods to form the male patterns of development, resulting in permanent sexually differentiated substrates. Later in life, ovarian and testicular hormones act differently in these substrates to establish the largest phenotypic sexual differences (Nef and Parada 2000).

The unified model (Arnold 2009) recognizes that SRY and other unidentified genes also linked to the $\mathrm{X}$ and $\mathrm{Y}$ chromosomes occupy the same primary level because they are all unequally encoded by the sex chromosomes in males and females. Some genes located on the $\mathrm{X}$ and $\mathrm{Y}$ chromosomes act differently in the gonads and other male and female tissues to cause sexual differences. SRY develops an important role in sexual differentiation throughout the life regulating the secretion of gonadal hormones, which have organizational and activation effects on the brain and other tissues. Then, due to independent sexual differences in the genes of sexual chromosomes and hormone secretion, several sex-specific factors produce synergistic effects to increase differences; however, they can also co-interact to reduce sexual differences.

\section{DEVELOPMENT OF MALE PHENOTYPE}

For the male phenotype development, in addition to XY chromosomes (Rosaet al. 2009), many authors have described expression of the SRY gene, which determines the differentiation of undifferentiated primordial gonad in a testicle, which regulate the differentiation of Sertoli cells (Nef and Parada 2000; Arnold 2009; Nakamura 2010; Blaschko et al. 2012).

The SRY gene acts in synergy with SF-1 gene and is activated by the WT- 1 gene (Wilms tumor suppressor locus-gene-1), which is expressed before gonadal differentiation, which also stimulates the transcription of AMH gene (antiMüllerian hormone) by Sertoli cells in differentiated testicular tissue (Domenice et al. 2002; Mello et al. 2005; Blaschko et al. 2012).
Expression of another genes as SOX9, LHX9, DAX-1 (Nef and Parada 2000; Mello et al. 2005; Nakamura 2010), CYP17 (Praporski et al. 2009) and the production of androgens by Leydig cells mediated by cytochrome P450c17, 3 $\beta$-HSD and $17 \beta$-HSD are also required for the differentiation of undifferentiated primordial gonad into a testicle and the production of androgens (Mello et al. 2005; Nakamura 2010).

Studies in transgenic mice $\mathrm{XX}$, introduced the SRY gene, showed male sexual phenotype, demonstrating the biological role of the SRY protein in the Sertoli cells activation (Koopman et al. 1991). Other studies in knockout mice demonstrated that the absence of WT-1 prevents the formation of kidney and testicles (Kreiberg et al. 2005).

The SRY gene is expressed in the cells of genital ridge, starting testicular development and transformation of precursor of support cells to Sertoli cells, which drive the development of other cells of the gonad, and thus the steroidal precursor cells develop in Leydig cells, while germinative cells generate the spermatogonia (Domenice et al. 2002).

Expression of the gene for protein STAR (steroidogenic acute regulatory protein) (Miller 2012) and CYP11A1 gene (cytochrome P450scc) in both the testes and ovaries is still necessary in order to start the production of steroid hormones. Studies in mice that lost these genes showed that the genital ridge was blocked and formation of gonad is disrupted (Nakamura 2010).

The 5 $\alpha$-reductase enzyme also participates directly in the conversion of testosterone to dihydrotestosterone (Merlet et al. 2007), which is a much more potent androgen (Nakamura 2010). This enzyme dependson the TMF (testicular feminization of mice) gene located into $\mathrm{Y}$ chromosome encoding androgen receptor protein. This mechanism starts in the Leydig cells where SF-1 gene regulates the expression of enzymes involved in steroid biosynthesis and testosterone may be converted to dihydrotestosterone. To perform their physiological functions, both hormones bind to androgen receptors on target cells, leading them to differentiation of Wolff ducts and external genitalia in males (Merlet et al. 2007; Blaschko et al. 2012). XY humans with $5 \alpha$ reductase deficiency have ambiguous genitalia, which at birth are more female-like than male-like (Yamada et al. 2003; Merlet et al. 2007). 
Nevertheless, there are several other genes involved in sexual differentiation in mammals, but the number of mechanisms have not yet been detailed (Nakamura 2010). In this respect, importance should be given to the VAMP-7 gene, which is directly related to the correct formation of the man's penis (Tannour-Louetet al. 2014).

The initial reproductive tract of embryo consists in two non-sexually differentiated gonads (Jost 1965; Vainio et al. 1999; Nef and Parada 2000; Nakamura 2014; Blaschko et al. 2012), two pairs of ducts, a urogenital sinus, a genital tubercle and vestibular folds. This system arises primarily from two germinative ridges at the dorsal part of abdominal cavity and may differentiate into the male or female system, a condition known as embryonic bisexuality. These gonads are formed by a group of large granular cells from yolk sac invading the germinative ridge (Wolpert 1998; Rosa et al. 2009).

Embryonic development of the urinary and genital tract is associated with the mesoderm (Merlet et al. 2007), where the nephrogenic cord gives three main segments for the development of the urogenital system; a cranial (pronephro), another medium (mesonephro) and a caudal (metanephro) (Sadler 2012).

In mammalian embryos, the initially undifferentiated structure through the coelomic epithelial proliferation coats the kidney and results in a germination plate. From that point, the dorsal and ventral pyramidal epithelium penetrates the germinal plate forming a genital ridge (Domenice et al. 2002; Moore and Persaud 2008; Blaschko et al. 2012).

The tubular system of genital organs originates from the tubules and ducts of pro and mesonephros (Wolff); the efferent duct of the testicles are formed from the tubules of mesonephros; the epididymis, vas deferens, vesicular glands and their ampoules are composed from the structures of mesonephros (Okay 2003). Some Wolff tubules that are separated from the ducts of mesonephros persist as vestiges along the epididymis and spermatic cord constituting the paradidymis, which are commonly found in the males of some species of mammals (Grunert et al. 2005; Moore and Persaud 2008).

The regression of the Müllerian ducts in males is the essential step in sexual differentiation (Vainio et al. 1999; Arnold 2009). This process is due to the presence of the $\mathrm{Y}$ chromosome containing
SRY gene, responsible for the testicular cell line support, resulting in the differentiation of precursor Sertoli cells and secretion of antiMüllerian hormone (Rey 2005; Blaschko et al. 2012), which induces regression of Müllerian duct. This hormone continues to be produced until puberty, and then decreases until reaching residual values (Okay 2003). The cell line of testicular interstice differentiates into Leydig cells, which produce testosterone, promoting the development of Wolff ducts and their subsequent derivative organs (Vainio et al. 1999; Domenice et al. 2002; Arnold 2009; Blaschko et al. 2012).

External genitalia originate from the central tuberosity of mesonephric cord. Before the sexual differentiation of embryo, a central genital tubercle (phallus) is formed, which results in the glans of penis flanked by two lateral elevations or genital folds, responsible for originating the corpus of penis and labia-scrotal saliences, which form the scrotum (Yamada et al. 2003; Blaschko et al. 2012). Dihydrotestosterone is required for the development of prostate, seminal vesicle and epididymis from Wolff duct (Domenice et al. 2002). Very low concentrations of this hormone may cause ambiguous genitalia (Mello et al. 2005).

Cloacal epithelium originating from the urethral portion of the endoderm form ventral portion of the penis and the urethra (Moore and Persaud 2008). The urethral opening depends on the correct balance in androgen and estrogen hormones, and the VAMP-7 gene is directly related to this balance (Tannour-Louet et al. 2014). The bulbourethral glands are formed as projections of urethra and may be found in the wall of the penile urethra (Grunert et al. 2005).

After the formation of the testicles, faults in sexual differentiation process can occur, which result in poor internal or external virilization in male genitalia. These changes can lead to male pseudo hermaphroditism, defects involving the synthesis of testicular steroids or pituitary hormones, and these hormones and receptors on target cells (Fig. 3) (Mello et al. 2005; Merlet et al. 2007).

Estrogens and androgens may cause sexual inversion in the male and female embryos for a brief period at the beginning of sexual differentiation. The age at which this bisexual potential is completely lost varies according to the species of vertebrates (Nakamura 2010). 


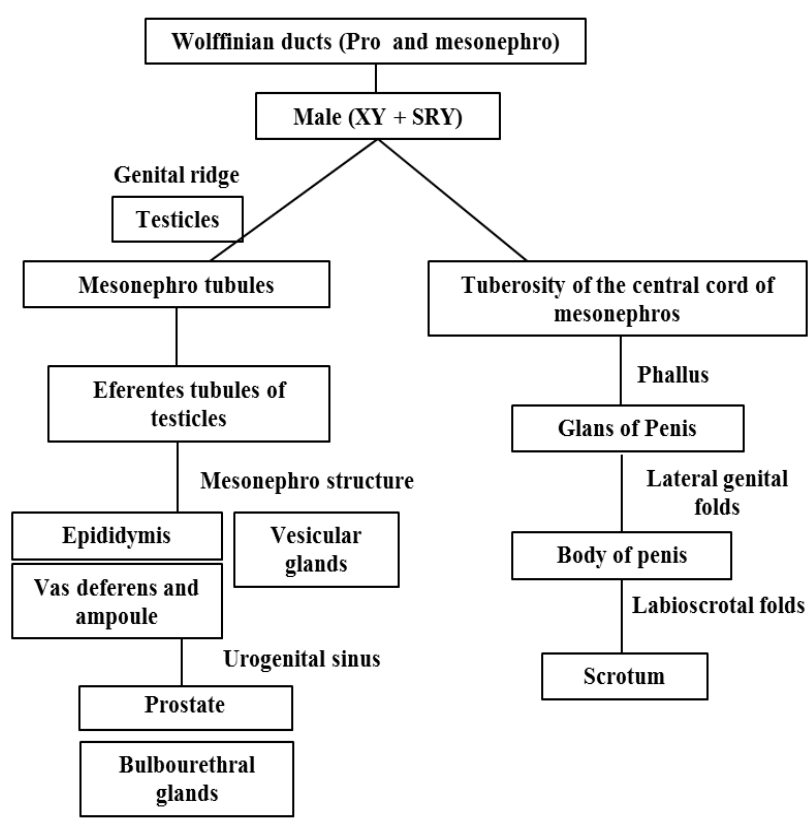

Figure 3 - Ilustration showing the main embryonic structures and their derived male genital organs.

\section{DEVELOPMENT OF FEMALE PHENOTYPE}

Both Wolff and Müller ducts are present in sexually undifferentiated embryo (Okay 2003). In the females, the Müllerian ducts develop into a duct-gonadal system and the Wolff ducts atrophy and in the males, the reverse occurs (Moore and Persaud 2008; Sadler 2012).

For the development of female phenotype the presence of XX chromosomes (Rosa et al. 2009), absence of the SRY gene (Arnold 2009; Nakamura 2010) and expression of DAX-1 and WNT-4 genes is required (Parker et al. 1999; Domenice et al. 2002; Mello et al. 2005). The cytochrome P450 aromatase enzyme encoded in the CYP 19 gene produces estrogen hormones in ovarian follicles, which is responsible for the development of female secondary characters (Conley and Hinshelwood 2001; Nakamura 2010; Yang et al. 2010; Bondesson et al. 2014). In the ovaries, DAX-1 protein binds to SF-1 and suppresses the expression of anti-Mullerian hormone. Mutations in WNT-4 gene do not cause disturbances in male development, however; in females, virilization with the absence of Müller ducts and maintenance of Wolff ducts is observed (Vainio et al. 1999).

The ovaries are formed by a group of large granulosa cells from yolk sac, which invade the germinative ridge. In females, two invasions occur. The first is abortive and the second results in the formation of sexual extensions of germinal epithelium and eventually become germinative cells (oogonia) (Sadler 2012). In experimental models, a large amount of primordial follicles were observed in the ovarian cortex of fetuses at the end of gestation (Santos et al. 2015).

In females, the absence of anti-Müllerian hormone in the intrauterine period allows the continued development of Müllerian duct and because of the absence of testosterone, the degeneration of the Wolff ducts occurs (Parker et al. 1999). However, the anti-Müllerian hormone begins to be produced in small amounts in ovarian granulosa cells from the birth until menopause. In women, this hormone is related to the activity of the aromatase enzyme (Okay 2003). In females, the development has been traditionally considered as a state that results primarily in the absence of testicular determining factor (SRY).The consequent absence of antiMullerian hormone and testosterone synthesis in the intrauterine period, results in the development of female gonads, steroidogenesis and maintenance of oocytes (Nef and Parada 2000; Domenice et al. 2002; Arnold 2009).

The Müllerian ducts in female fetuses fuse caudally to form the uterus, cervix and the anterior portion of the vagina (Vainio et al. 1999; Okay 2003). Müllerian ducts are initially formed at the top of the coelomic cavity and gradually grow caudally into the pelvis, where merge medially, and the caudal growth of these ducts contacts the urogenital sinus. The not fused portions become the uterine tubes and the most caudal portion, uterus and vagina. The dorsal wall of the vagina is considered as Müllerian-derived, and the ventral wall is prevenient of the urogenital sinus (Domenice et al. 2002; Moore and Persaud 2008; Rosa et al. 2009; Santos et al. 2011).

The origin of vaginal epithelium is scientifically controversial because it could originate from the paramesonephric ducts or urogenital sinus or perhaps a double origin (Grunert et al. 2005).

In females, the weak tunica albuginea of the gonad prevents retrograde migration of gonocytes from the germinal epithelium and causes the proliferation in the basal zone of epithelioid cell cords, which are compact and constitute the ovarian plexus, which partly remain in the adult animal as epoophoro that may become cystic in several species of mammals. The caudal portions of mesonephros form the paroophoro which are 
aberrant ducts and tubules,posteriorly located to ovary (Grunert et al. 2005).

The female external genitalia originate from the central tuberosity of the mesonephric cord. Before the sexual differentiation of the embryo, it forms a central genital tubercle (phallic), flanked by two lateral elevations or genital folds and labioscrotal folds (Domenice et al. 2002; Yamada et al. 2003; Blaschko et al. 2012).

The central tubercle gives rise at clitoris and female genital lateral folds emerge by fusion the vulvar lips (Santos et al. 2015). The urethral septum in the embryonic development of mammals makes the separation of endodermal cloaca, allowing the formation and isolation of urogenital and rectal areas (Domenice et al. 2002; Moore and Persaud 2008; Rosa et al. 2009; Blaschko et al. 2012).

The urogenital folds do not fuse completely, except in the posterior region, which merge to form the frenulum of the labia minora, while the clitoris arises from a slight lengthening of the genital tubercle and the opening of the genital sulcus becomes the vaginal vestibule in humans (Moore and Persaud 2008; Rosa et al. 2009). The hymen arises from the urogenital sinus invagination, resulting in the expansion of the caudal portion of the vagina (Blaschko et al. 2012; Hegazy and Al-Rukban 2012) (Fig. 4).

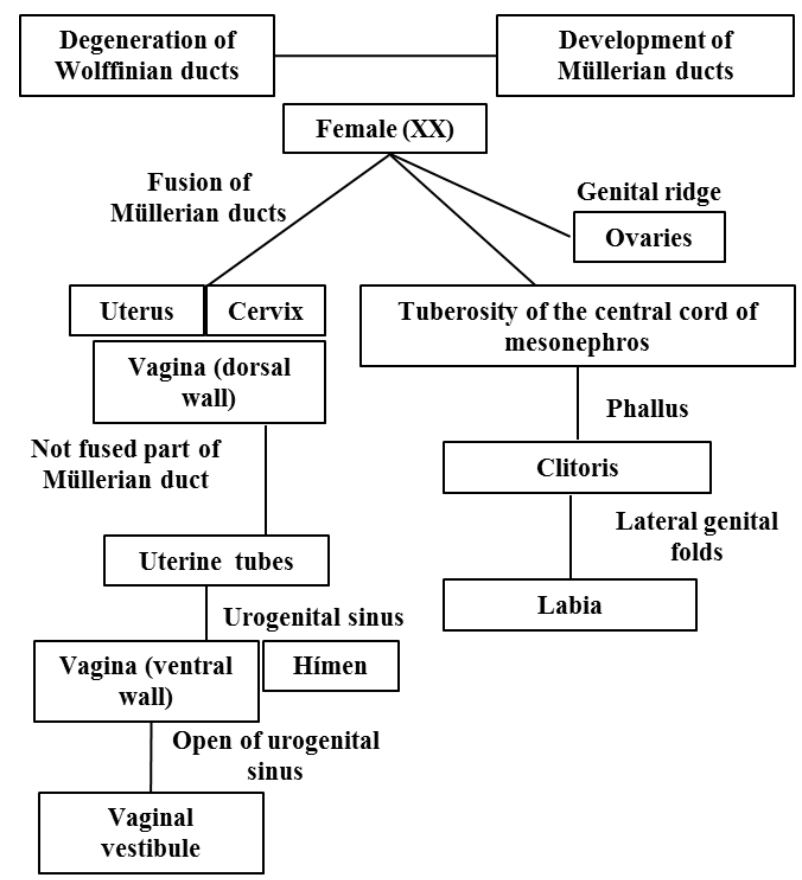

Figure 4 - Ilustration showing the main embryonic structures and their derived female genital organs.
The greater vestibular glands known as Bartholin's glands develop in the vaginal vestibule and are homologous to bulbourethral glands of males (Grunert et al. 2005).

The correct sexual development is dependent on the differentiation of somatic cells in the gonads and the appropriate production and reception of hormones produced in the gonads (Vainio et al. 1999). In addition, estrogen hormones converted by the cytochrome P450 aromatase enzyme from androgens (Praporski et al. 2009) are essential for the differentiation of female secondary characters (Bondesson et al. 2014).

It is essential to emphasize that if faults occur in embryonic development, alterations or prevention of full activity of regulatory substances of sexual differentiation process may result in anomalies in the selected individuals (Nakamura 2010; Yang et al. 2010; Blaschko et al. 2012; Santos et al. 2014b).

\section{MORPHOLOGICAL ABNORMALITIES RELATED TOSEXUAL DIFFERENTIATIONPROCCESS}

In the complex process involved in the sexual differentiation, numerous enzymes, hormones and their receptors, and transcription factors are present. Possible defects in genes encoding the synthesis of any of these substances are essential to the appearance of anomalies related to sexual differentiation (Domenice et al. 2002).

Among various pathologies related to the sexual differentiation, the syndrome Mayer-RokitanskyKuster-Hauser (SMRKH) could be highlighted, which occurs in one out of 4500 women. This syndrome consists of agenesis or dysgenesis of Müllerian portion of the vagina and uterus, which is determined during embryogenesis process of female genital organs; however, the external genital organs and the hymen are normal in this case (Pizzo et al. 2013).Uterine malformations are the result of development failures, reabsorption or fusion of Müllerian ducts. The SMRKH was first reported by Columbus in 1562. Later, Mayer in 1829 and Rokitansky in 1838 described the changes found in an autopsy, then called uterus bipartitus. Küster in 1910 proposed surgical therapies and Hauser in 1962 defined the syndrome consisting of: normal external genitalia, absent vagina, absent or rudimentary uterus and uterine tubes and normal ovaries (Santos et al. 2011). 
Among the genetic syndromes associated with female pseudohermaphroditism, the Seckel syndrome with genital alterations as clitoromegaly and labia minor hypoplasia could be mentioned (Arnold et al. 1999). The syndrome McKusickKaufman characterized by hydrometrocolpos and vaginal agenesis with the presence of urogenital sinus or absence of urethral or external vaginal orifice could also be highlighted (Slavotinek and Biesecker 2000).

Virilization of the female genitalia may occur by androgen accumulation, resulting from the hyperplasia of the adrenal cortex, which is related to CYP11A1 gene (P450scc), 3- $\beta$-HSD enzyme, CYP 17 gene (P450c17), CYP21A2 gene (21hydroxylase) and CYP $11 \mathrm{~b} 1$ gene $(11 \beta$ hydroxylase) (Mello et al. 2005). Congenital adrenal hyperplasia occurs due to the lack of the enzyme 21- $\beta$-hydroxylase, generating high levels of androgens, forming an individual with $\mathrm{XX}$ sex chromosomes, which develops ambiguous genitalia due to hypertrophy of the clitoris (Nóbrega et al. 2004).

Syndrome of Müllerian duct persistence is a rare disease of autosomal recessive genetic origin, which causes defects in the action and synthesis of anti-Müllerian hormones in the individuals with $\mathrm{XY}$ karyotype, which have normal male phenotype, but have bilateral cryptorchidism, inguinal hernias, and often have uterus and uterine tubes located in the inguinal canal or abdomen (Okay 2003).

In the males, it has recently been discovered that double VAMP-7 gene abnormally modulating estrogen receptors is responsible for penile hypospadias, which is characterized by abnormal closing of the urogenital sulcus during the fetal period, and therefore results in an abnormal opening of the urethra in the penis (Tannour-Louet et al. 2014).

Another case involves testicular feminization in $\mathrm{XY}$ individuals that develops into a vagina, clitoris, large and small labial lips. However, the gonads are male. This form of sexual differentiation disorder is caused by the lack of androgen receptors in target tissues (Merlet et al. 2007), and for this reason, the male external genitalia does not develop. However, there is development of the ducts of Wolff and the production of anti-Müllerian hormone by the testes, which leads to the regression of Müllerian ducts. For this reason, the individual does not develop uterus and uterine tubes (Costanzo 1998). The XY familiar gonadal dysgenesis (lack of testicular differentiation), syndrome of uterine hernia characterized by the permanence of the Müllerian ducts and presence of infant uterus in $\mathrm{XY}$ individuals, and male gynecomastia are due to defects in testosterone synthesis. The male pseudohermaphroditism, with presence of female external genitalia is characterized by genetic disorders, especially in the expression of steroidogenic enzymes (Nora and Fraser 1989).

Other anomalies of sexual differentiation are sexual infantilism in women, syndrome of polycystic ovary (Costanzo 1998; Nóbrega et al. 2004; Martin et al. 2008; Costenaro et al. 2010; Kalfa et al. 2010) and androgen insensitivity from mutations in the genes of these receptors that generate $\mathrm{XY}$ individuals with female external genitalia at birth (Domenice et al. 2002).

In addition to these above described disorders, many other diseases are the subject of several studies, which intrigue scientists around the world and raise many questions about the importance of sexual steroid hormones and gene expression associated with sexual chromosomes during the sexual differentiation process (Gaucher et al. 2004; Arnold 2009; Miller 2012; Tannour-Louet et al. 2014).

In summary, the sexual differentiation process comprises chromosomal sex XX or XY + SRY and other genes linked to them, differentiation of undifferentiated gonads in the testicles or ovaries, differentiation of internal and external genital organs from the male or female undifferentiated embrionary structures, which is dependent on the presence or absence of the testicles and production of anti-Müllerian hormone and testosterone. The secondary sexual differentiation occurs in various tissues due to the hormones produced by the gonads, which interact with the genes linked to the sex chromosomes to increase or decrease the differences in the male and female sexual phenotype.

\section{ACKNOWLEDGEMENTS}

To FAPESP (Fundação de Amparo a Pesquisa do Estado de São Paulo) for financial support. 


\section{REFERENCES}

Arnold AP. The organizacional-activacional hypothesis as the foundation for a unified theory of sexual differentiation of all mammalian tissues. Horm Behav. 2009; 55(5): 570-578.

Arnold AP, Chen X. What does the "four core genotypes" mouse model tell us about sex differences in the brain and other tissues? Front Neuroendocrinol. 2009; 30(1): 1-9.

Arnold SR, Spicer D, Kouseff B, Lacson A, GilbertBarness E. Seckel-like syndrome in three siblings. Pediatr Dev Pathol. 1999; 2(2): 180-187.

Bernardo-Filho M, Santos-Filho SD, Fonseca AS, Carter K, Missailidis S. Nuclear medicine procedures for the evaluation of male sexual organs: a brief review. Braz Arch Biol Technol. 2008; 51(special): 13-21.

Blaschko SD, Cunha GR, Baskin LS. Molecular mechanisms of external genitalia development. Differentiation. 2012; 84(3): 261-268.

Bondesson M, Hao R, Lin C-Y, Williams C, Gustafsson J-A.Estrogen receptor signaling during vertebrate development. Biochim BiophysActa. 2014; Epub ahead of print

Conley AJ, Corbin CJ, Browne P, Mapes SM, Place NJ, Hughes AL et al. Placental expression and molecular characterization of aromatase cytochrome P450 in the spotted hyena (Crocutacrocuta). Placenta. 2006; 28(1): 668-675.

Conley A, Hinshelwood M. Mammalian Aromatases. Reproduction. 2001; 121(5): 685-695.

Costanzo LS.Physiology. Philadelphia: Saunders Company, 1998, 392p.

Costenaro F, Rodrigues TC, Kater CE, Auchus RJ, Papari-Zareei M, Czepielewski MA. Combined $17 \alpha-$ hydroxylase/17,20-lyase deficiency due to p.R96W mutation in the CYP17 gene in a Brazilian patient. Arq Bras Endocrinol Metab. 2010; 54(8): 744-748.

Domenice S, Costa EMF, Corrêa RV, Mendonça BM. Molecular aspects of sexual determination and differentiation. Arq Bras Endocrinol Metab. 2002; 46(4): 433-443.

Gaucher EA, Graddy LG, Li T, Simmen RCM, Simmen FA, Schreber DR et al. The planetary biology of cytochrome P450 aromatases. BMC Biology. 2004; 2(19): 1-14.

Grunert E, Birgel EH, Vale NG. Patologia e clínica da reprodução dos animais mamíferos domésticos (ginecologia). São Paulo: Varela, 2005, 412p.

Hegazy AA, Al-Rukban MO. Hymen: facts and conceptions. The Health. 2012; 3(4): 109-115.

Jost A. Gonadal hormones in the sex differentiation of the mammalian fetus. In: Urpsrung RL, Dehaan H, editors. Organogenesis. New York: Holt, Rinehart and Winston; 1965. p 611-628.
Kalfa N, Méduri G, Philibert P, Patte BBB, Thibaut E, Pienkowski $\mathrm{C}$ et al. Unusual virilization in girls with juvenile granulosa cell tumors of the ovary is related to intratumoral aromatase deficiency. Horm Res Paediatr. 2010; 74(2): 83-91.

Koopman P, Gubbay J, Vivian N, Goodfellow P, Lovell-Badge R. Male development of chromosomally female mice transgenic for SRY. Nature. 1991; 351(6322): 117-121.

Kreiberg JA, Sariola H, Loring JM, Maeda M, Pelletier $\mathrm{J}$, Housman D et al. WT1 is required for early kidney development. Cell. 2005; 49(1): 14-25.

Martin MR, Oliveira PSL, Costa EMFC, Arnhold IJP, Mendonça BB. Combined 17 AlphaHydroxylase/17,20-Lyase deficiency due to a homozygous 25 BP duplication (NT 4157-4181) at Exon 5 in the CYP17 resulting in a premature stop codon predicted by molecular modeling. Arq Bras Endocrinol Metab. 2008; 52(8): 1317-1320.

Mello MP, Assumpção JG, Hackel C. Genes involved in sex determination and differentiation. Arq Bras Endocrinol Metab. 2005; 49(1): 14-25.

Merlet J, Moreau E, Habert R, Racine C. Development of fetal testicular cells in androgen receptor deficient mice.Cell Cycle. 2007; 6(18): 2258-2262.

Miller WL. The syndrome of 17,20 lyase deficiency. $J$ Clin Endocrinol Metab. 2012; 97(1): 59-67.

Moore K, Persaud TVN. Embriologia Básica. 8.ed. São Paulo: Elsevier, 2008, 462p.

Nakamura M. The mechanism of sex determination in vertebrates are sex steroids the key-factor? J Exp Zool Part A: Ecol Gen Physiol. 2010; 313(7): 381-398.

Nef S, Parada LF. Hormones in male sexual development. Genes Develop. 2000; 14: 3075-3086.

Nóbrega LHC, Lima JG, Nóbrega MLC, Brito ALS, Mendonça RP. Congenital adrenal hyperplasia: measurement of basal 17-hydroxyprogesterone as a screening test to select patients for the synthetic ACTH provocative test. Rev Bras Ginecol Obstet. 2004; 26(4): 295-298.

Nora JJ, Fraser FC. Medical Genetics: Principles and Practice. Philadelphia: Lea \& Febiger, 1989, 301p.

Norman WA, Litwack G. Hormones. 2. ed. San Diego: Academic Press, 1997, 873p.

Okay TS. Hormônio anti-Mülleriano: importância na prática pediátrica. Rev Assoc Med Bras. 2003; 49(1): 16-17.

Parker KL, Schedl A, Schimmer BP. Gene interactions in gonadal development. Annual Rev Physiol. 1999; 61(1): 417-433.

Pelley JW. Integrated Biochemistry. Rio de Janeiro: Elsevier, 2007, 230p.

Phoenix CH, Goy RW, Gerall AA, Young WC. Organizing action of prenatally administered testosterone propionate on the tissues mediating mating behavior in the female guinea pig. Endocrinology. 1959; 65(3): 369-382. 
Pizzo A, Laganà AS, Sturlese E, Retto G, Retto A, Dominici R, et al. Mayer-Rokitansky-Kuster-Hauser syndrome: embryology, genetics and clinical and surgical treatment. ISRN Obstetr Gynecol. 2013; ID 62871.

Praporski S, Nq SM, Nguyen AD, Corbin CJ, Mechler A, Zheng J. Organization of cytochrome P450 envolved in sex steroids synthesis. J Biol Chem. 2009; 284(48): 33224-33232.

Rey R. Anti-Müllerian hormone in disorders of sex determination and differentiation. Arq Bras Endocrinol Metabol. 2005; 49(1): 26-36.

Rosa BRT, Fereira MMG, Martins IS, Beltran MP. Determinação do sexo e desenvolvimento dos órgãos sexuais. Rev Cient Elet Med Vet. 2009; 7(12): 1-7.

Sadler TW. Langman's Medical Embryology. 12. ed. Philadelphia: Lippincott Williams \& Wilkins, 2012, 400p.

Santos RR, Barbosa TB, Vieira PSM, Dumont LQ, Canuto AL. Syndrome Mayer-Rokitansky-KusterHauser (SMRKH): case report. RevMéd Minas Gerais. 2011; 21(3): 321-323.

Santos AC, Oliveira M, Viana D, Assis-Neto AC. Sexual differentiation of the external genitalia in embryos and fetuses in the spix's yellow-toothed cavy (Galea spixii). Placenta. 2014a; 35(9): A25.

Santos AC, Bertassoli BM, Viana DC, Vasconcelos BG, Oliveira MF, Miglino MA, Assis-Neto AC. The morphology of female genitalia in Galea spixii (Caviidae, Caviinae). Biosc J. 2014b;30(6):17931802.

Santos AC, Favaron PO, Viana DC, Silva FMO, Alcântara D, Vasconcelos BG, et al. Development of the female genital organs in cobaias $C$. porcellus. Animal Reprod. 2015; 12(1): 171-172.
Simpson ER, Clyne C, Rubin G, Boon WC, Robertson K, Britt K. Aromatase-a brief overview. Annual Rev Physiol. 2002; 64(1): 93-127.

Slavotinek AM, Biesecker LG. Phenotypic overlap of McKusick-Kaufman syndrome with Bardet-Biedl syndrome: a literature review. Am J Med Gen. 2000; 95(3): 208-215.

Stryer L. Bioquímica. 4. ed. Rio de Janeiro: Guanabara Koogan, 1996, 1000p.

Tannour-Louet M, Han S, Louet J-F, Zhang B, Romero K,Addai J et al. Increased gene copy number of VAMP7 disrupts human male urogenital development through altered estrogen action. Nature Med. 2014; 20(7): 715-726.

Vainio S, Heikkilä M, Kispert A, Chin N, McMahon AP. Female development in mammals is regulated by WNT4 signaling. Nature. 1999; 351(6718): 405-409.

Viana DC, Santos AC, Assis-Neto. Immunolocalization of enzymes: cytochrome P450 aromatase, and cytochrome P450c17 (17- $\alpha$-hidroxilase/17, 20 lyase) in the epididymis of the freshwater turtle (Kinosternonscorpioides) in the dry and rainy seasons. Animal Reprod. 2015; 12(1): 181-182.

Wolpert L.Principles of Development.London: Oxford University Press, 1998, 484p.

Yamada G, Satoh Y, Baskin LS, Cunha GR. Cellular and molecular mechanisms of development of the external genitalia. Differentiation. 2003; 71(8): 445460.

Yang JH, Menshenina J, Cunha GR, Place N, Baskin LS. Morphology of mouse external genitalia: implications for a role of estrogen in sexual dimorphism of the mouse genital tubercle. J Urol. 2010;184(4): 1604-1609. 